\title{
BRPKM
}

Buletin Riset Psikologi dan Kesehatan Mental

http://e-journal.unair.ac.id/index.php/BRPKM

e-ISSN: 2776-1851

ARTIKEL PENELITIAN

\section{Pengaruh Work Life Balance Terhadap Psychological Well-Being Pada Karyawan Work From Home}

\author{
DEVINA OCTA FRISDAYANTI \& SEGER HANDOYO* \\ Fakultas Psikologi Universitas Airlangga
}

\begin{abstract}
ABSTRAK
Suatu penelitian yang dilakukan untuk mengetahui bagaimana pengaruh keseimbangan kehidupan kerja terhadap kesejahteraan psikologis pada karyawan yang bekerja dari rumah dengan regulasi emosi sebagai variabel moderator. Menggunakan tipe pendekatan kuantitatif melalui metode pengambilan data, salah satu syarat subjek pada penelitian ini adalah karyawan yang sedang/pernah menjalani bekerja dari rumah, dengan kriteria bekerja di suatu perusahaan sejumlah 106 orang. Alat ukur pada penelitianmenggunakan skala keseimbangan kehidupan kerja. Hasil dari analisis ditunjukkan bahwa terdapat pengaruh pada keseimbangan kehidupan kerja dan kesejahteraan psikologis seseorang, dengan arah pengaruh yang negatif $(p=0,000)$. Bahwa pada penelitian ini regulasi emosi tidak memoderasi pengaruh antara keseimbangan kehidupan kerja dengan kesejahteraan psikologis ( $\mathrm{p}=$ 0,437).
\end{abstract}

Kata kunci: emotional regulation, psychological well-being, work life balance.

\section{ABSTRACT}

A study was conducted to determine how the effect of work life balance on the psychological well being of employees working from home with the regulation of emotions as a moderating variable. Using a quantitative approach via data collection methods, one of the requirements of the subject of this study is employees who currently worked/have worked from home, with the criterion of working in a company of up to 106 people. The results of that there is an influence between work-life balance and psychological well-being, with a direction of negative influence $(p=0.000)$. That in this study, emotion regulation did not moderate the effect between work-life balance and psychological well-being $(\mathrm{p}=$ 0.437).

Keywords: emotional regulation, psychological well-being, work life balance.

Buletin Penelitian Psikologi dan Kesehatan Mental (BRPKM), 2021, Vol. 1(2), 1457-1461

*Alamat korespondensi: Fakultas Psikologi Universitas Airlangga, Kampus B Universitas Airlangga Jalan Airlangga 4-6 Surabaya 60286. Surel: seger.handoyo@psikologi.unair.ac.id

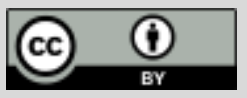

Naskah ini merupakan naskah dengan akses terbuka dibawah ketentuan the Creative Common Attribution License (CC-BY-4.0) (http://creativecommons.org/licenses/by/4.0), sehingga penggunaan, distribusi, reproduksi dalam media apapun atas artikel ini tidak dibatasi, selama sumber aslinya disitir dengan baik. 


\section{PEN D A H U L U A N}

Organisasi Kesehatan Dunia (WHO) mengumumkan bahwa covid-19 atau coronavirus disease 2019 sebagai pandemi (Sohrabi dkk., 2020). Di Indonesia sendiri sampai hari ini tercatat sekitar 54.662 orang meninggal dan 1,99 juta orang terkonfirmasi positif covid-19. Pemerintah mengeluarkan berbagai kebijakan kepada masyarakat khususnya pekerja atau karyawan yang dapat melakukan pekerjaannya dari rumah untuk melakukan work from home (WFH) dalam mengurangi penyebaran virus.

Accenture (2012) melakukan sebuah studi dengan partisipan karyawan yang bekerja pada suatu perusahaan di beberapa negara. Pada penelitian tersebut ditemukan bahwa Indonesia termasuk dalam tingkat kepuasaan dan kebahagiaan karyawan yang terendah. Kita bisa melihat bahwa apabila tingkat kesejahteraan psikologis karyawan akan semakin rendah maka berdampak pada kesejahteraan psikologi pada karyawan.

Menurut Fisher dkk., (2009) bahwa work life balance meliputi empat aspek penting, yakni waktu, perilaku, ketegangan, dan energi. Menurut penelitian Wilkinson (2013), bahwa terdapat hubungan signifikan antara keseimbangan kehidupan kerja dengan kesejahteraan psikologis seseorang. Karyawan yang memiliki kesejahteraan yang baik dan positif maka kehidupan dan pekerjaannya lebih seimbang. Menurut Lathifah dkk., (2020), karyawan dengan kesejahteraan psikologis yang baik akan memiliki tingkat absensi yang rendah, tepat waktu dan efisien, juga dapat bekerja lebih lama di perusahaan.

Melihat masih adanya ketidakpuasan dan ketidakbahagiaan karyawan terhadap pekerjaannya secara psikologis, peneliti memiliki keinginan lebih jauh untuk mengungkap pengaruh keseimbangan kehidupan kerja dengan kesejahteraan psikologi pada karyawan yang melakukan pekerjaannya dari rumah atau dikenal dengan work from home di tengah masa pandemi. Maka peneliti melakukan penelitian terkait hal tersebut.

\section{Desain Penelitian}

\section{E T O D E}

Pada penelitian ini menggunakan salah satu metode penelitian, yaitu metode kuantitatif dengan tipe penelitian survei. Penelitian kuantitatif merupakan penelitian yang diolah menggunakan metode statistika dan menekankan pada data-data yang bersifat numerik (Azwar, 2013). Kemudian berdasar pada tujuan penelitian, penelitian ini dapat digolongkan penelitian eksplanatori.

\section{Partisipan}

Partisipan penelitian merupakan sampel dalam suatu penelitian. Sampel penelitiantersebut ditentukan sehingga dapat mewakili populasi dari suatu penelitian. Berikut adalah karakteristik partisipan dalam penelitian ini adalah laki-laki atau perempuan dewasa, merupakan karyawan di sebuah perusahaan/instansi/organisasi, dan pernah/sedang menjalani work from home.

\section{Pengukuran}

Dalam penelitian ini dilakukan menggunakan teknik metode kuesioner berupa pertanyaan-pertanyaan yang disusun berdasarkan dimensi dari alat ukur variabel penelitian. Skala yang digunakan kuesioner ini adalah skala likert, sebagai skala yang paling umum digunakan, pada penelitian dengan metode survei (Neuman, 2011). Pengukuran psychological well-being terdiri dari 42 aitem dari Ryff \& Keyes, (1995) dan memiliki reliabilitas $(\alpha=.88)$. Pengukuran work life balance menggunakan skala dari Banu \& Duraipandian, (2014) yang terdiri dari 45 aitem dan memiliki reliabilitas $(\alpha=.79)$. Kemudian untuk pengukuran regulasi emosi terdiri dari 10 aitem dari Gross \& John, (2003) dengan memiliki nilai reliabilitas $(\alpha=.80)$. Untuk semua skala menggunakan 5 skala likert yaitu skor 1 adalah sangat tidak

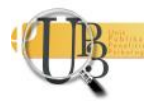


setuju hingga skor 5 adalah sangat setuju. Ketiga alat ukur tersebut menggunakan face validity yang dilakukan oleh professional judgement masing-masing dalam pengujian alat ukurnya.

\section{Analisis Data}

Teknik dalam penelitian ini menggunakan program IBM SPSS Statistic 25 for macbook. Teknik dalam analisis data pada penelitian ini menggunakan uji analisis regresi linear sederhana. Untuk melakukan uji analisis regresi linear sederhana, perlu dilakukan beberapa uji asumsi. Uji asumsi adalah uji normalitas, dari uji tersebut plot yang terlihat menunjukkan tidak ada penyimpangan distribusi yang tidak normal. Sehingga, distribusi data bisa dianggap normal. Kedua adalah uji regresi linear sederhana, dari uji tersebut mendapatkan hasil bahwa work life balance berpengaruh terhadap psychological wellbeing.

\section{HAS I L P EN ELITIAN}

Subjek pada penelitian ini yaitu 106 orang. Subjek tersebut terdiri dari 62 orang berjenis kelamin lakilaki $(58,5 \%)$ dan 44 orang berjenis kelamin perempuan (41,5\%). Rentang usia subjek yaitu berkisar antara usia 21 sampai dengan diatas 50 tahun. Dengan jumlah subjek untuk rentang usia 21-30 tahun sebanyak 40 orang $(37,6 \%)$, untuk rentang usia 31-40 tahun sebanyak 37 orang $(34,1 \%)$, rentang usia 41-50 tahun sebanyak 29 orang $(28,3)$.

Hasil uji statistik deskriptif yang diperoleh dapat diketahui bahwa dalam penelitian ini, yaitu 106 subjek. Variabel psychological well-being memiliki nilai sebesar $\left(R=72 ; N_{\min }=104,00 ; N_{\max }=176,00\right)$. Kemudian untuk variabel work life balance memiliki nilai sebesar $\left(R=72 ; N_{\min }=122,00 ; N_{\max }=194,00\right)$. Regulasi emosi memiliki nilai sebesar $\left(R=38,72 ; N_{\min }=26,00 ; N_{\max }=50,00\right)$.

\section{I S K U S I}

Berdasarkan hasil analisis, penelitian ini menemukan bahwa tidak terdapat pengaruh langsung yang signifikan antara work life balance terhadap psychological well being. Kemudian, dapat diketahui juga bahwa variabel regulasi emosi sebagai variabel moderator pada penelitian ini tidak memoderasi antara kesejahteraan psikologis dengan keseimbangan kehidupan kerja, oleh karena itu Ha2 pada penelitian ini tidak diterima. Kemudian pada penelitian ini juga dapat diketahui bahwa regulasi emosi berpengaruh terhadap psychological well being yang membuat pada penelitian ini diterima. Maka dapat disimpulkan bahwa regulasi emosi berpengaruh langsung sebagai variabel independen terhadap psychological well being bukan memoderasi pengaruh work life balance terhadap psychological well being.

Berdasarkan hasil penelitian tersebut menunjukkan sebagian partisipan (62,5\%) memiliki work life balance pada kategori sangat tinggi dan psychological well being (55\%) berada pada kategori sangat tinggi. Dapat diketahui pula bahwa dalam penelitian ini, variabel moderator yaitu regulasi emosi tidak memoderasi pengaruh keseimbangan kehidupan kerja pada kesejahteraan psikologis. Hal itu disebabkan oleh signifikansi yang melebihi 0,05 pada hasil moderate analysis regression. 987 Hasil analisis pada penelitian ini juga menunjukan bahwa terdapat pengaruh langsung regulasi emosi terhadap psychological well being. Tingkat psychological well being dapat diminimalisir dengan kemampuan regulasi emosi (Extremera \& Rey, 2015). Psychological wellbeing, karena individu dengan kemampuan regulasi emosi yang baik dikatakan dapat mempertahankan emosi positif serta meminimalisir emosi negatif. Dapat diketahui pula bahwa dalam penelitian ini, variabel moderator yaitu 
regulasi emosi tidak memoderasi pengaruh work life balance terhadap psychological well-being. Hal itu disebabkan oleh signifikansi yang melebihi 0,05 pada hasil moderate analysis regression.

Regulasi emosi yang tidak memoderasi pada penelitian ini dapat terjadi karena berbagai alasan, salah satunya yaitu terdapat variabel lain yang dapat memoderasi pengaruh work life balance terhadap psychological wellbeing lebih signifikan daripada regulasi emosi. Terdapat pengaruh langsung regulasi emosi terhadap psychological well-being. Konsekuensi negatif serta dampak ddari stress serta rendahnya tingkat psychological well-being dapat diminimalisir dengan kemampuan regulasi emosi. Hasil analisis pada penelitian ini juga menunjukkan pengaruh yang signifikan pada variabel bebas yaitu keseimbangan kehidupan kerja untuk dimensi peningkatan efektivitas di tempat kerja, dimensi kepuasan, serta dimensi gangguan kehidupan pribadi dengan variabel terikat yaitu kesejahteraan psikologis. Kemudian untuk hasil dimensi gangguan pekerjaan dengan kehidupan pribadi terhadap kesejahteraan psikologis tidak terdapat pengaruh dan juga berlaku untuk dimensi dukungan tempat kerja serta dimensi penekan yang tidak terdapat pengaruh signifikan.

\section{S I M P U L A N}

Dari hasil penelitian dengan analisis dan pembahasan yang sudah dijelaskan, maka dapat disimpulkan:

1. Adanya pengaruh signifikan antara kesejahteraan psikologis dan keseimbangan kehidupan kerja pada karyawan yang sedang/pernah bekerja dari rumah.

2. Terdapat variabel regulasi emosi sebagai variabel moderator pada penelitian ini tidak memoderasi pengaruh keseimbangan kehidupan kerja terhadap kesejahteraan psikologis pada karyawan bekerja dari rumah

3. Sebagai variabel independen yaitu, regulasi emosi. Dan karena regulasi emosi berpengaruh secara langsung terhadap kesejahteraan psikologis

Adapun suatu hasil simpulan dari penelitian ini adalah bisa menjadi petunjuk bagi perusahaan/instansi/organisasi lebih memperhatikan faktor yang dapat mempengaruhi keseimbangan kehidupan kerja karena hal tersebut dapat mempengaruhi kesejahteraan psikologis pada karyawan. Seperti memperhatikan kepuasan kerja dan tetap memperhatikan jam kerja dan pekerjaan yang diberikan. Perusahaan dapat mengadakan pelatihan atau seminar mengenai regulasi emosi agar karyawan dapat mengetahui pentingnya regulasi emosi dan dapat mempertahankan bahkan meningkatkan kesejahteraan psikologis mereka.

\section{U C A P A N T ER I MAKASIH}

Penulis mengucapkan terima kasih kepada seluruh pihak yang terlibat dalam proses pembuatan penelitian ini, dan terima kasih untuk Fakultas Psikologi Universitas Airlangga yang telah memfasilitasi terlaksananya penelitian ini."

\section{DEKLARASI POTENSI TERJADINYAKONFLIK KEPENTINGAN}

Devina Octa Frisdayanti dan Seger Handoyo tidak bekerja, menjadi konsultan, memiliki saham, atau menerima dana dari perusahaan atau organisasi manapun yang nantinya mungkin akan mengambil untung dari diterbitkannya naskah ini.

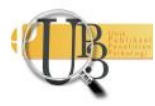




\section{PUSTAKA ACUAN}

Accenture. (2012). The Path Forward: International Women's Day 2012 Global Research Results.

Azwar. (2013). Metode Penelitian. Yogyakarta: Pustaka Pelajar.

Banu, A. R., \& Duraipandian, K. (2014). Development of an Instrument To Measure Work Life Balance of It Professionals in Chennai. International Journal of Management, 5(11), 21-33.

Extremera, N., \& Rey, L. (2015). The moderator role of emotion regulation ability in the link between stress and well-being. Frontiers in Psychology, 6(OCT). https://doi.org/10.3389/fpsyg.2015.01632

Fisher, G. G., Bulger, C. A., \& Smith, C. S. (2009). Beyond Work and Family: A Measure of Work/Nonwork Interference and Enhancement. Journal of Occupational Health Psychology, 14(4), 441-456. https://doi.org/10.1037/a0016737

Gross, J. J., \& John, O. P. (2003). Individual Differences in Two Emotion Regulation Processes: Implications for Affect, Relationships, and Well-Being. Journal of Personality and Social Psychology, 85(2), 348-362. https://doi.org/10.1037/0022-3514.85.2.348

Lathifah Z. K., Helmanto F., \& Maryani N.. (2020). The Practice of Effective Classroom Management in COVID-19 Time. International Journal of Advanced Science and Technology, 29(7), 3263-3271.

Neuman, W. L. (2011). Social research methods: qualitative and quantitative approaches.

Ryff, C. D., \& Keyes, C. L. M. (1995). The Structure of Psychological Well-Being Revisited. Journal of Personality and Social Psychology. https://doi.org/10.1037/0022-3514.69.4.719

Sohrabi, C., Alsafi, Z., O’Neill, N., Khan, M., Kerwan, A., Al-Jabir, A., Iosifidis, C., \& Agha, R. (2020). World Health Organization declares global emergency: A review of the 2019 novel coronavirus (COVID19).International Journal of Surgery, 76(February), https://doi.org/10.1016/j.ijsu.2020.02.034

Wilkinson, J., \& Ahern, n. R. (2013). Buku Saku Diagnosis keperawatan edisi 9. In Diagnosis NANDA, Intervensi NIC, Kriteria hasil NOC. Jakarta: EGC. 